\title{
Hemipelvectomy Type II
}

National Cancer Institute

\section{Source}

National Cancer Institute. Hemipelvectomy Type II. NCI Thesaurus. Code C157649.

A hemipelvectomy with the resection confined to the periacetabulum. 